\title{
THE REAL ESTATE MARKET IN RUSSIA IN JANUARY 2013 G.Zadonsky
}

In January 2013, entities of all the forms of ownership built 45,800 new apartments with the total floorspace of $3.58 \mathrm{~m}$ sq. meters or $114.7 \%$ as compared to January 2012. In January, individual developers commissioned 1,585m sq. meters of housing which is 6.2\% more than in January 2012.

The average floorspace of apartments built in 2012 decreased by $0.56 \%$ as compared to 2011 and amounted to 78.9 sq. meters (Fig. 1). On the contrary, the average floorspace of apartments built by households in 2012 at their own account and by means of borrowed funds increased by $3.5 \%$ as compared to 2011 and amounted to 137.6 sq. meters.

In 2012, the average actual cost of building of a sq. meter of housing in the Russian Federation increased by $2.62 \%$ as compared to 2011. Along with that, the average price of a sq. meter of housing (all the apartments) on the primary market increased by $10.25 \%$ in that period, while that on the secondary market, by $16.85 \%$. Accordingly, the ratio of the average price of a sq. meter of housing on the primary market and the average actual cost of building of a sq. meter of housing amounted to $140.86 \%$ (Fig. 2).

According to the Rosstat, in 2012 the highest cost of building which exceeded by over $50 \%$ the average national level was observed in Moscow (Rb 63,317), the Sakhalin Region ( $\mathrm{Rb} 58,940$ ), the Yamal-Nenetsk Autonomous Region (Rb 54,762), the Nenetsk Autonomous Region (Rb 53,949) and the Kamchatka Territory (Rb 53,676). In 55 constituent entities of the Russian Federation that cost was below the average national level with the lowest one in the Kursk Region (Rb 22,000), the Republic of Adygeya ( $\mathrm{Rb} 22,230)$ and Dagestan (Rb 22,491).

As of January 2013, the housing availability index (HAI) as a ratio of the cost of a standard apartment with floorspace of 54 sq. meters to the annual income of a family of three persons

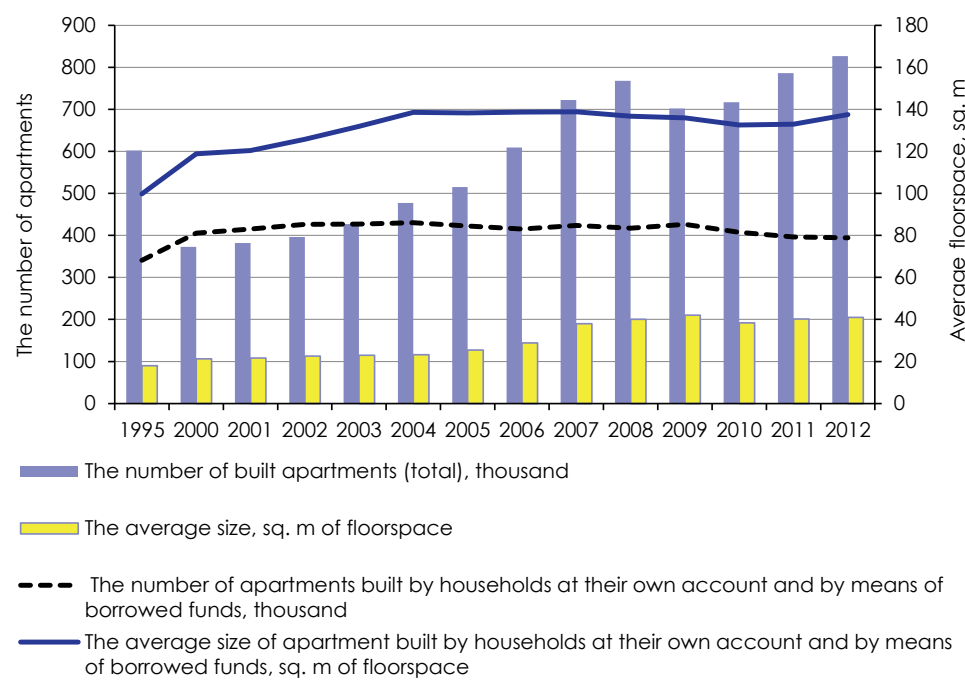

Source: On the basis of the data of Rosstat.

Fig. 1. The number of apartments built in the Russian Federation and their average floorspace

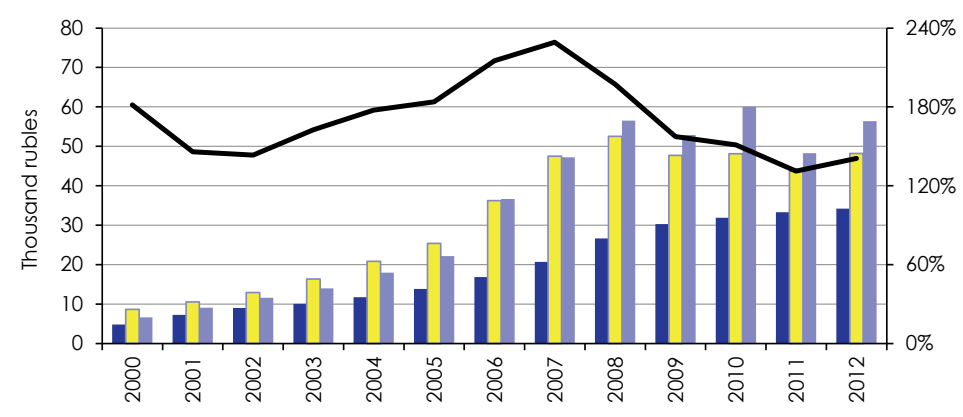

Average actual cost of building of a sq. meter of housing, thousand rubles**

$\square$ Average price of a sq. meter of housing on the primary market, thousand rubles***

Average price of a sq. meter of housing on the secondary market, thousand rubles***

Average price of a sq. meter of housing on the primary market as \% of the average actual cost of building of a sq. $m$ of housing

* The average actual cost of building of a sq. meter of floorspace of detached dwelling houses (all the apartments) without extensions, overstory and built-in premises in the Russian Federation (without those built by households at their own account and by means of borrowed funds);

** All the apartments.

Source: On the basis of the Rosstat's data.

Fig. 2. Dynamics of the cost of building of housing and prices on the primary and secondary housing markets in 2012 


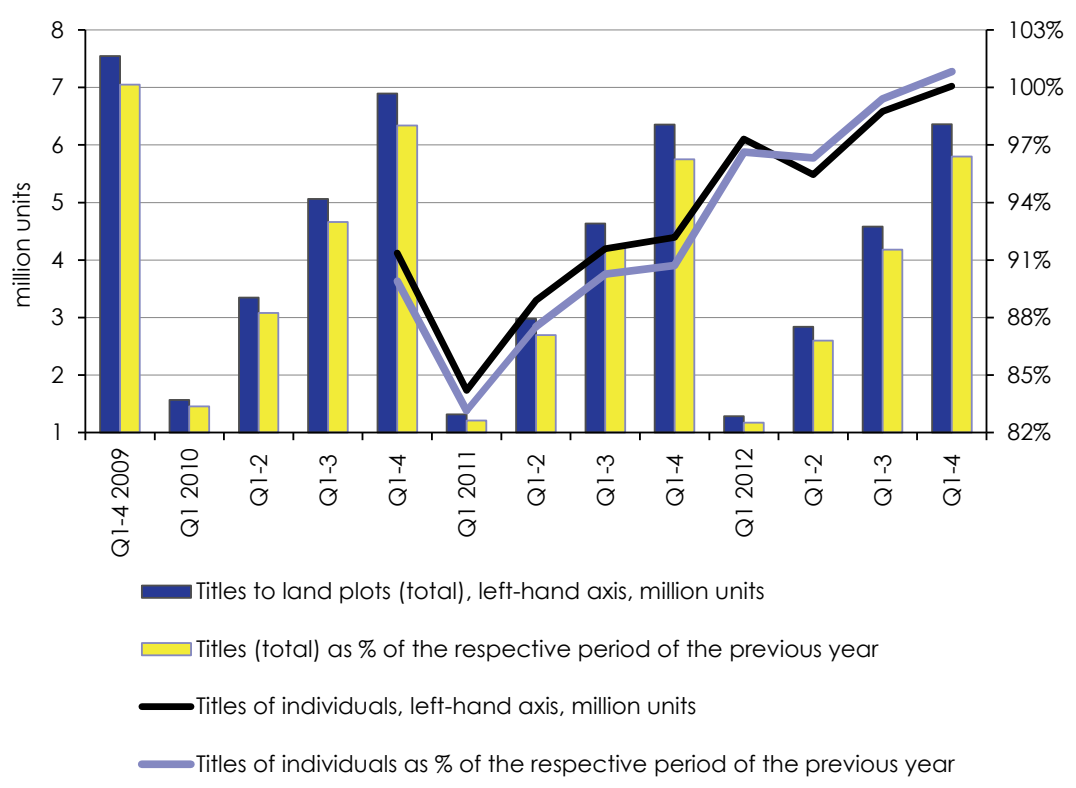

Source: Data of Rosreestr.

Fig. 3. Dynamics of registration of titles to land plots

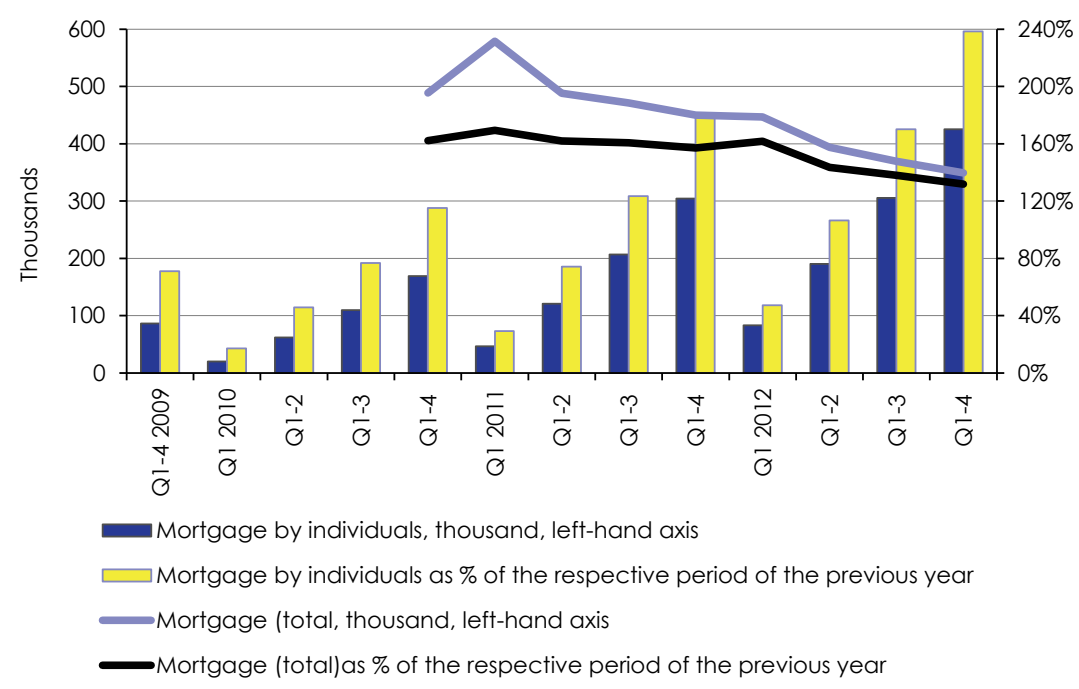

Source: Data of Rosreestr.

Fig. 4. Dynamics of registration of land mortgages

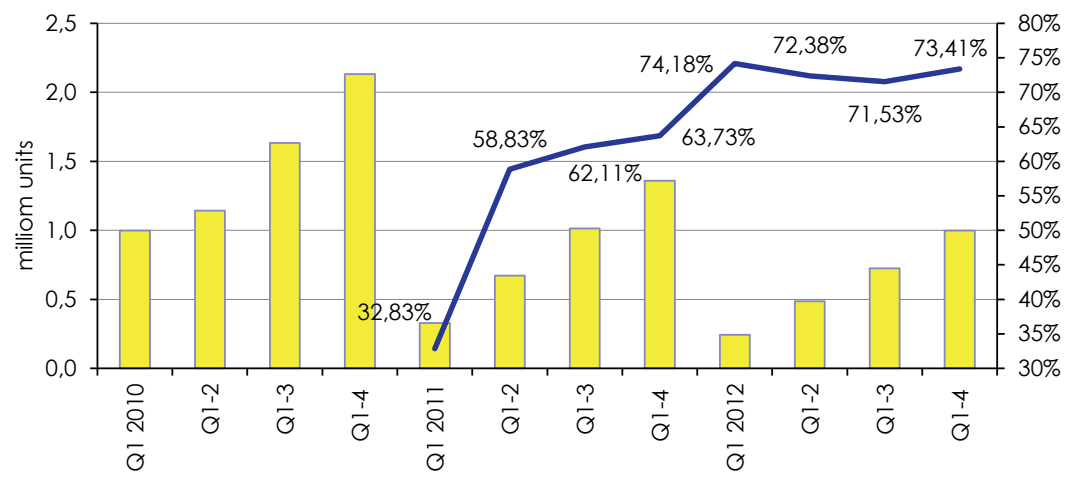

$\square$ Registration of individuals' titles to some real property in accordance with the simplified procedure, million units Registration of individuals' titles to some real property in accordance with the simplified
procedure as \% of the respective period of the previous year

Source: Data of the Rossreestr.

Fig. 5. The dynamics of registration of individuals' titles to some real property in accordance with the simplified procedure (the summer cottage amnesty) amounted on the primary market and the secondary market to 3.28 years and 3.37 years, respectively, which is $1.3 \%$ and $5.99 \%$ higher than the respective HAI index as of January 1, 2012. The latter is evidence of a decrease in availability of housing in 2012 as compared to 2011 ; it is to be noted that the decrease on the secondary market was more rapid than on the primary one. Unlike the year 2012, in 2011 the HAI on the primary market and the secondary market was $12.65 \%$ and $29.22 \%$ lower, respectively, than in 2010 .

According the data of Rosreestr, in 2012 the number of the registered titles to land plots, including those of individuals slightly exceeded the results of 2011 , but was still below those of 2010 and 2009. In 2012, registration of individuals' titles to land plots amounted to $91.15 \%$ of the total volume of registration of titles to land plots or $5,796 \mathrm{~m}$ certificates (Fig. 3).

The growth rates of the number of land mortgages by individuals exceed growth rates of land mortgages in general. In 2012, the volume of land mortgages by individuals exceeded by $40 \%$ the volume of 2011 and amounted to $71.34 \%$ of the total number of land mortgages or 425,125 certificates (Fig. 4).

In 2012 , the volume of individuals' titles to some real property - the so-called " summer cottage amnesty" where titles were registered in accordance with a simplified procedure - amounted to 997,332 certificates which was $26.59 \%$ and $53.22 \%$ less than the volume of 2011 and 2010, respectively (Fig. 5).

From January 1, 2013, cadastral accounting of buildings, constructions and unaccomplished building projects is carried out entirely - in accordance with the 
law on the cadastral register of real property - by the Rosreestr represented by the Cadastral Chamber. In the transition period until January 1, 2014 the Technical Inventory Bureau will keep performing the function of development of technical plans which include the grid data on the location of the real property project and the location data on the premises inside the building.

According to the data of Rosreestr, under Federal Law No. 302-FZ of December 30, 2012 from March 1, 2013 no state registration of agreements on purchase and sale of housing, agreements on purchase and sale of an enterprise as a property complex, deeds of gift of real property and annuity agreements, including those with condition of permanent alimony with maintenance is required, but subject to state registration is assignment of the title to the alienated property as a result of such transactions. In entering into such agreements, the state duty is to be paid only for state registration of the title. Along with that, the President of the Russian Federation signed Federal Law No.21-FZ of March 4, 2013 by which an amendment was introduced in Law No.302-FZ; under the above amendment the rules of state registration of agreements on lease of real property were reestablished.

According to the data of the Central Bank of the Russian Federation, in January 2013 35,875 housing loans for the total amount of $\mathrm{Rb} 54,106 \mathrm{bn}$, including 33,643 mortgage housing loans for the amount of $\mathrm{Rb} 52,213 \mathrm{bn}$ were extended. As compared to January 2012, the number of the extended MHL rose by $18.9 \%$, while their volume in monetary terms, by $34.23 \%$. As of February 1, 2013, the outstanding debt on MHL in rubles increased by $42.72 \%$ as compared to February 1, 2012 and amounted to $\mathrm{Rb} 1.89$ trillion, while that on loans in foreign currency decreased by $21.45 \%$ and amounted to $\mathrm{Rb} 119,993 \mathrm{bn}$.

As of February 1, 2013, the overdue debt on MHL amounted to Rb 41,912bn (Rb 28,159bn on loans in rubles and $\mathrm{Rb} 13,753 \mathrm{bn}$ on loans in foreign currency). As of the above date, the overdue debt on MHL in foreign currency as a percentage of the outstanding debt decreased by 0.71 p.p. as compared to February 1, 2012 and amounted to $11.46 \%$, while the share of the overdue debt on MHL in rubles decreased within the same period by 0.49 p.p. and amounted to $1.49 \%$ (Fig. 6). As of February 1, 2013, the aggregate overdue debt amounted to $2.08 \%$ of the total debt which figure was 0.02 p.p. and 0.95 p.p. lower than that as of January 1, 2013 and February 1, 2012, respectively.

As of February 1, 2013, the amount of the debt on defaulted MHL (with a period of delay for over 180 days) decreased to $\mathrm{Rb} 29,957 \mathrm{bn}$ or $1.49 \%$ of the total amount of the debt which is 0.77 p.p. and 2.08 p.p. lower than that as of January 1, 2013 and February 1, 2012, respectively. The share of the debt on MHL without overdue payments decreased by 0.02 p.p. to $95.91 \%$ as compared to January 1, 2013 and increased by 2.66 p.p. as compared to February 1, 2012.

In January 2013, the average value of MHL in rubles amounted to $\mathrm{Rb} 1.53 \mathrm{~m}$ which is $12.24 \%$ higher than that in January 2012; the average amount of MHL in foreign currency amounted to $\mathrm{Rb} 8.54 \mathrm{~m}$ which is $61.06 \%$ higher than that in January 2012.

In January 2013, the weighted average rate on loans extended within a month amounted to $12.7 \%$ on MHL in rubles which figure was 0.9 p.p. higher than the value of the rate as of February 1, 2012 (Fig. 7), while that on MHL in foreign currency, to $9.0 \%$, which was 0.7 p.p. lower than that in January 2012. In January 2013, the weighted average period of lending as regards MHL

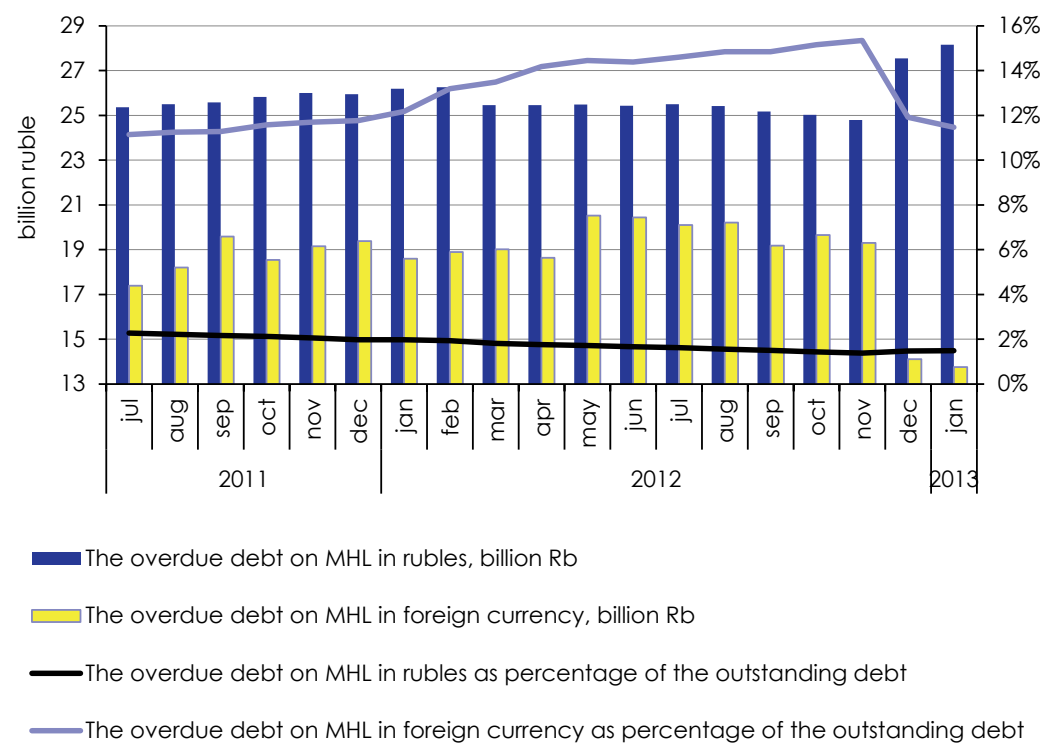

Source: The basis of the data of the Central Bank of the Russian Federation

Fig. 6. The dynamics of overdue debt on MHL 


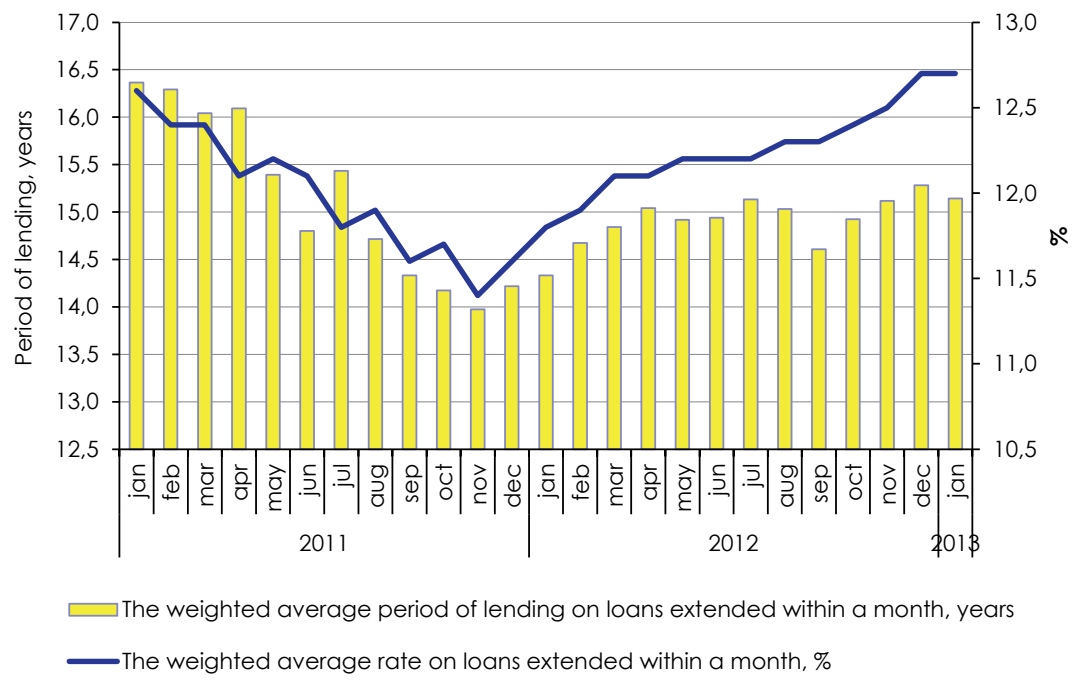
tion.

Source: The basis of the data of the Central Bank of the Russian Federa-

Fig. 7. The weighted average periods and weighted average interest rates on MHL in rubles extended within a month

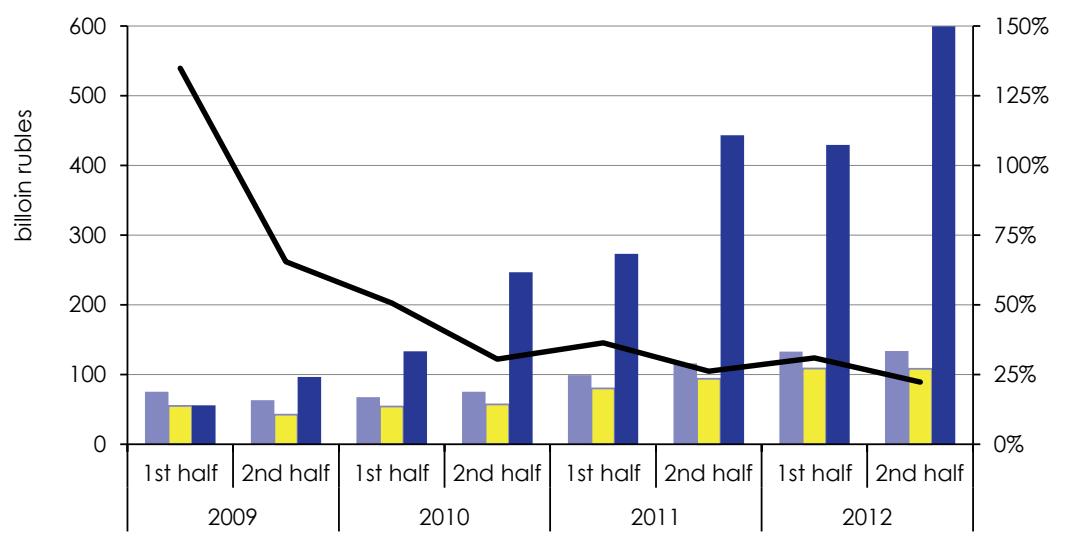

The volume of early paid MHL (total), billion $\mathrm{Rb}$

$\square$ The volume of MHL early paid by means of borrowers' funds, billion Rb

The volume of MHL extended within a half-year, billion Rb

-The total volume of early paid MHL as \% of the volume of the extended MHL

Source: The basis of the data of the Central Bank of the Russian Federation.

Fig.8. Dynamics of early paid MHL in rubles amounted to 15.14 years which was 0.81 year more than in January 2012, while that as regards MHL in foreign currency, to 9.66 years which was 4.24 years less than in January 2012.

In January 2013, the share of MHL in foreign currency in the total volume of loans extended within a month amounted in money terms to $1.49 \%$ against $0.9 \%$ in January 2012. The debt on MHL in foreign currency as percentage of the total debt on the extended loans was steadily decreasing and amounted to $5.97 \%$ as of February 1, 2013 .

In the second half of 2012 , the volume of MHL repaid before maturity amounted in money terms to $\mathrm{Rb} 133,667 \mathrm{bn}$, having exceeded by $14.98 \%$ the respective value of the second half of 2011 (Fig.8).

In the second half of 2012 , the volume of funds collected from borrowers as a result of realization of mortgaged property amounted to Rb 2,175bn (Fig. 9) which was $20.88 \%$ lower than that in the second half of 2011. Within the same period, the volume of funds collected from borrowers decreased by 0.84 p.p. to $5.22 \%$ and 0.26 p.p. to $0.36 \%$ in relation to the overdue debt on MHL and the volume of the extended MHL, respectively (Fig.9).

According to the data of the Central Bank of the Russian Federation, in the second half of 2012 the volume of refinanced MHL which included both a sale of the pool of loans and preservation of

the asset on the balance of the credit institution ${ }^{1}$ amounted to Rb $71.14 \mathrm{bn}$ or $11.87 \%$ of the volume of MHL extended within that period which figure was $14.53 \%$ lower in terms of the volume as compared to the second half of 2011 and 6.9 p.p. lower as percentage of the volume of MHL extended within that period (Fig. 10).

In January-February 2013, OAO AHML bought back 5.67 mortgages by all the products for the amount of $\mathrm{Rb} 7,564 \mathrm{bn}$ which is $9.53 \%$ higher than the volume of the repurchased mortgages in

1 Refinancing of MHL is assignment of rights of claim to mortgage housing loans by virtue of an agreement on financing against such an assignment with preservation of the asset on the balance of the credit institution - on the basis of such an asset the credit institution creates derivative financial instruments, in particular, mortgage-backed securities. Refinancing of MHL (rights of claim to mortgage housing loans) with sale of a pool of MHL is based on the sale of the asset both without formation of an additional financial instrument and with further issuing of mortgage-backed securities. 
money terms in January-February 2012.

According to the forecast provided by AHML, in 2013 it is expected to provide 707,000 to $808,000 \mathrm{HL}$ for the amount of $\mathrm{Rb} 1,092 \mathrm{bn}$ to $\mathrm{Rb} 1,248 \mathrm{bn}$, including 669,000 to 764,000 MHL for the total amount of Rb 1,050bn to $\mathrm{Rb}$ 1,200bn. The volume of MHL on the primary market will amount to 201,000 to 229,000 loans for the total amount of $\mathrm{Rb} 315,000 \mathrm{bn}$ to $\mathrm{Rb} 360,000 \mathrm{bn}$, while that on the secondary market amounts to 468,000 to 535,000 loans for the total sum of Rb 735,000bn to $\mathrm{Rb} 840,000 \mathrm{bn}$. The floorspace of housing bought under MHL will amount to $26 \mathrm{~m}$ sq. m. to $28 \mathrm{~m} \mathrm{sq}$, $\mathrm{m}$., including that on the primary market in the volume of $8.7 \mathrm{~m}$ sq. $\mathrm{m}$. to $9.3 \mathrm{~m}$ sq. m. It is expected that within a year the weighted average rate on MHL in rubles will not exceed $13.5 \%$. Also, the share of mortgaged property projects in the total number of property projects registered in transactions with housing is expected to amount to $20 \%$ to $23 \%$.

From January 1, 2013, the Law on Mortgage-Backed Securities as amended came into force; according to the amendments the mortgage agent which is registered as a joint-stock company is granted the right to raise funds by issuing mortgage-backed securities.

For the first time in Russia, a MHL securitization deal has been transacted by means of issuing by the Obrazovanie Bank and ZAO GFT Kapital Management Company of $\mathrm{Rb} 1,250 \mathrm{bn}$ worth of mortgage certificates of participation (MSP). Respective rules of trust management of the mortgage collateral of MSP were registered by the Federal Financial Markets Service in July 2012.

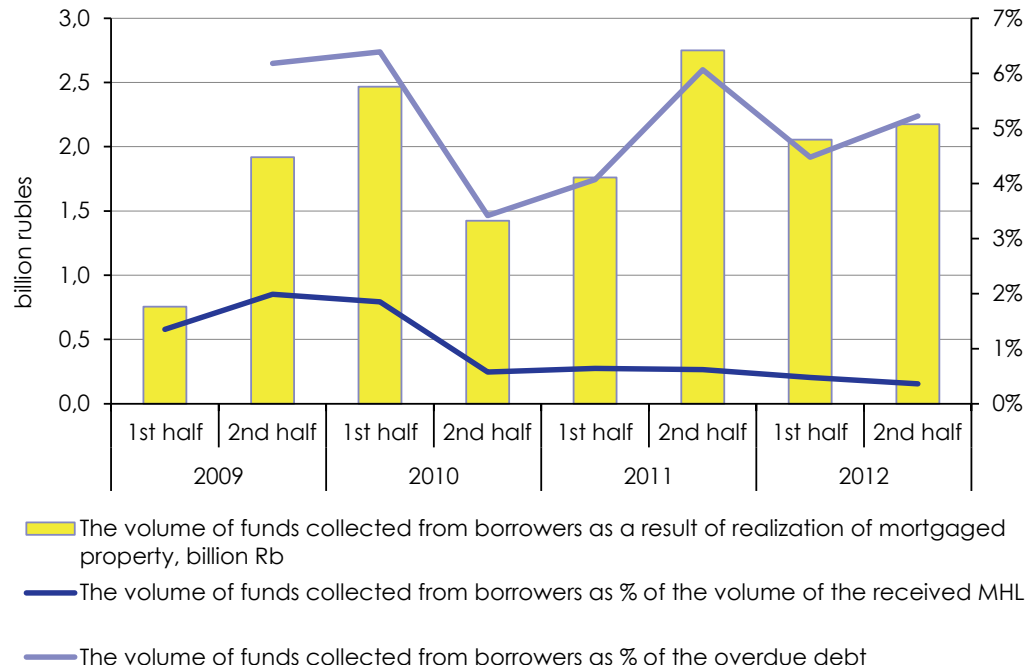

Source: The basis of the data of the Central Bank of the Russian Federation

Fig.9. The dynamics of the volume of funds collected from borrowers as a result of realization of mortgaged property

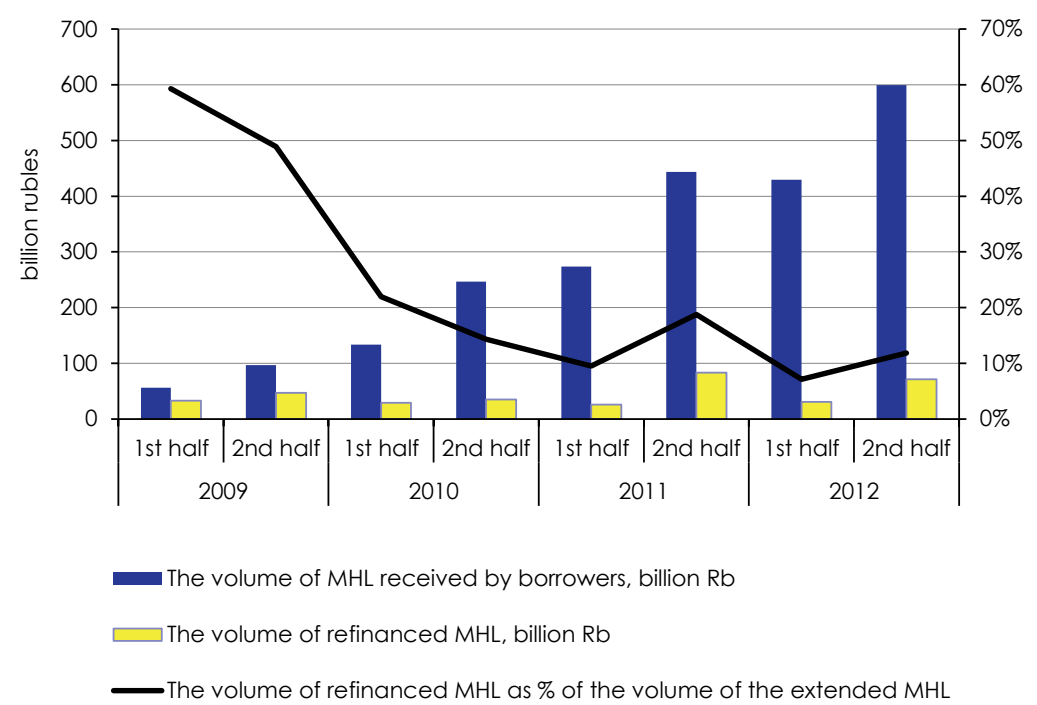

Source: The basis of the data of the Central Bank of the Russian Federation

Fig. 10. Dynamics of refinancing of MHL (rights of claim) 